\title{
STRENGTHENING OF RC SLAB WITH MULTIPLE OPENING BY NSM TECHNIQUE
}

\section{Sobhan Babu Panditi ${ }^{1}$, Harish Naik Banoth ${ }^{2}$}

Senior Site Engineer, Navayuga Engineering Company Limited, Palamuru Rangareddy Lift Irrigation, Kollapur, Telangana, India ${ }^{1}$

Assistant Professor, Department of Civil Engineering, Shri Shirdi Sai Institute of Science \& Engineering (SSSS), Vadiyampeta, Anantapur, Andhra Pradesh, India ${ }^{2}$

\section{ABSTRACT}

This paper presents the Near Surface Mounted (NSM) FRP rods are now emerging as a promising technique, in addition to externally bonded FRP laminates, for increasing flexural and shear strength of RC members. Introducing openings in existing reinforced concrete (RC) slabs can severely weaken the slabs due to the cut out of both concrete and reinforcing steel. In this thesis, the use of Glass Fibre Reinforced Polymers (GFRP) strengthening alternatives to restore the flexural capacity of the RC slab after having multiple openings in the slab have been studied.

KEYWORDS: RC slab, Openings, Strengthening, GFRP rods, NSM technique.

\section{INTRODUCTION}

Glass fiber-reinforced polymer (GFRP) rebar is slowly gaining market share as government entities begin to include it in building codes and design guidelines and as test methods have been developed. As a result, a growing number of agencies, such as the Manitoba Floodway Authority, have selected GFRP rebar as the most effective long-term solution for public projects. The use of corrosionresistant composite rebar will ensure the guide ways long-term durability and, thus, will extend the train system's useful life and reduce maintenance/repair costs.

\section{RESEARCH SIGNIFICANCE}

Strengthening of RC slabs with symmetrical openings using GFRP composite beams were studied by Yeoi Choi et al. [1] with two symmetrical openings and one-half scale with a dimension of slab $3000 \mathrm{~mm} \times 2000 \mathrm{~mm} \times 150 \mathrm{~mm}$ and with two openings of $300 \mathrm{~mm} \times 400 \mathrm{~mm}$. The results shows that there is an increasing the load carrying capacity. Seliem et al. [2] studied the flexural capacity on the existing multi-story RC structure. Three different strengthening techniques externally bonded CFRP laminates EBCFRP laminates with CFRP anchors and Near Surface Mounted (NSM) CFRP strip were studied. Test results showed that the three strengthening techniques enhanced the load-carrying capacities of the slabs with openings with the NSM technique more effective than the EB technique. Smith and Kim [3] investigated the strength of Fiber Reinforced Polymer (FRP) strengthened one-way RC slab with central cut-outs and achieved higher load carrying capacity 
than the unstrengthened controlled specimens. Laboratory studies are reported by Ola Enochsson et al [4], L.Michel et al. [5], Agbossou et al [6] and Gilles Foreta and OualidLimam [7].

The advantage is primarily the resistance of FRP to corrosion, a property that is particularly important in this case due to the position of the rods very close to the surface. Very limited literature is available to date on the use of NSM FRP rods for structural strengthening.

\section{PROPERTIES OF MATERIALS USED}

\subsection{MATERIALS}

Ordinary Portland cement of 53 grade, confirming to IS 12269:1987, locally available river sand as fine aggregate (zone-II) confirming to IS-383, coarse aggregates maximum size was $20 \mathrm{~mm}$ were used in this investigation. The physical properties of the cement, fine aggregate and coarse aggregate are presented in Table 1. GFRP rebar of $8 \mathrm{~mm}$ diameter were used.

Table: 1 Material Testing

\begin{tabular}{|c|c|c|c|}
\hline S. No & Name of the test & Value & Codal values \\
\hline 1 & Specific gravity of cement & 3.14 & \\
\hline 2 & Standard consistency of cement & $32 \%$ & \\
\hline 3 & Initial setting time of cement & 70 minutes & $\begin{array}{l}\text { Should not be less } \\
\text { than } 30 \text { minutes (IS } \\
12269-1987 \text { ) }\end{array}$ \\
\hline 4 & Final setting time of cement & 440 minutes & $\begin{array}{l}\text { Should not be more } \\
\text { than } 600 \text { minutes (IS } \\
12269-1987 \text { ) }\end{array}$ \\
\hline 5 & Compressive strength of cement cubes & $58 \mathrm{Mpa}$ & $\begin{array}{l}\text { Not less than } 53 \mathrm{Mpa} \\
\text { (IS 12269-1987) }\end{array}$ \\
\hline 6 & Specific gravity of fine aggregate & 2.64 & \\
\hline 7 & Water absorption of coarse aggregate & $0.4 \%$ & \\
\hline 8 & Aggregate Impact value & $7.1 \%$ & \\
\hline
\end{tabular}

\subsection{PROPORTIONS OF CONCRETE}

In the process of mix designing, the suitable ingredients of concrete and determining their relative amounts with the objective of producing a concrete of the required strength, durability and workability has been achieved. The amount of cement, fine aggregate and coarse aggregate are calculated based upon the code IS 10262: 2009.

The mix proportions are shown in Table 2. 
Table: 2 Mix proportions of concrete

\begin{tabular}{|c|c|c|c|c|c|}
\hline S.No & $\begin{array}{c}\text { Water cement } \\
\text { ratio }\end{array}$ & $\begin{array}{c}\text { Water } \\
(\mathrm{Kgs})\end{array}$ & Cement (Kgs) & $\begin{array}{c}\text { Fine aggregate } \\
(\mathrm{Kgs})\end{array}$ & $\begin{array}{c}\text { Coarse } \\
\text { Aggregate } \\
(\mathrm{Kgs})\end{array}$ \\
\hline 1 & 0.50 & 191.60 & 383.00 & 688.19 & 1131.35 \\
\hline
\end{tabular}

\subsection{PREPARATION OF TEST SPECIMENS}

A total of five RC slabs having dimensions of $1050 \mathrm{~mm} \times 1050 \mathrm{~mm} \times 70 \mathrm{~mm}$ were fabricated using the 28 -day average concrete compressive strength of $23.55 \mathrm{MPa}$ and the average concrete split tensile strength of $2.49 \mathrm{MPa}$.

There were 2 control slabs casted with and without openings and 3 slabs were casted with opening and kept under strengthening.

The control slab without opening is specified as CS1 and the control slab with opening without strengthening is denoted as CS2 are shown in figure 1.

The slabs with openings which were strengthened using GFRP rebar as external reinforcement placed around the opening denoted as SS1 and strengthened in diagonal form with one GFRP rebar on each groove named as SS2 and then the slabs strengthened with two GFRP rebar's on each groove in diagonal form around the opening named as SS3 respectively are shown in figure 2 .

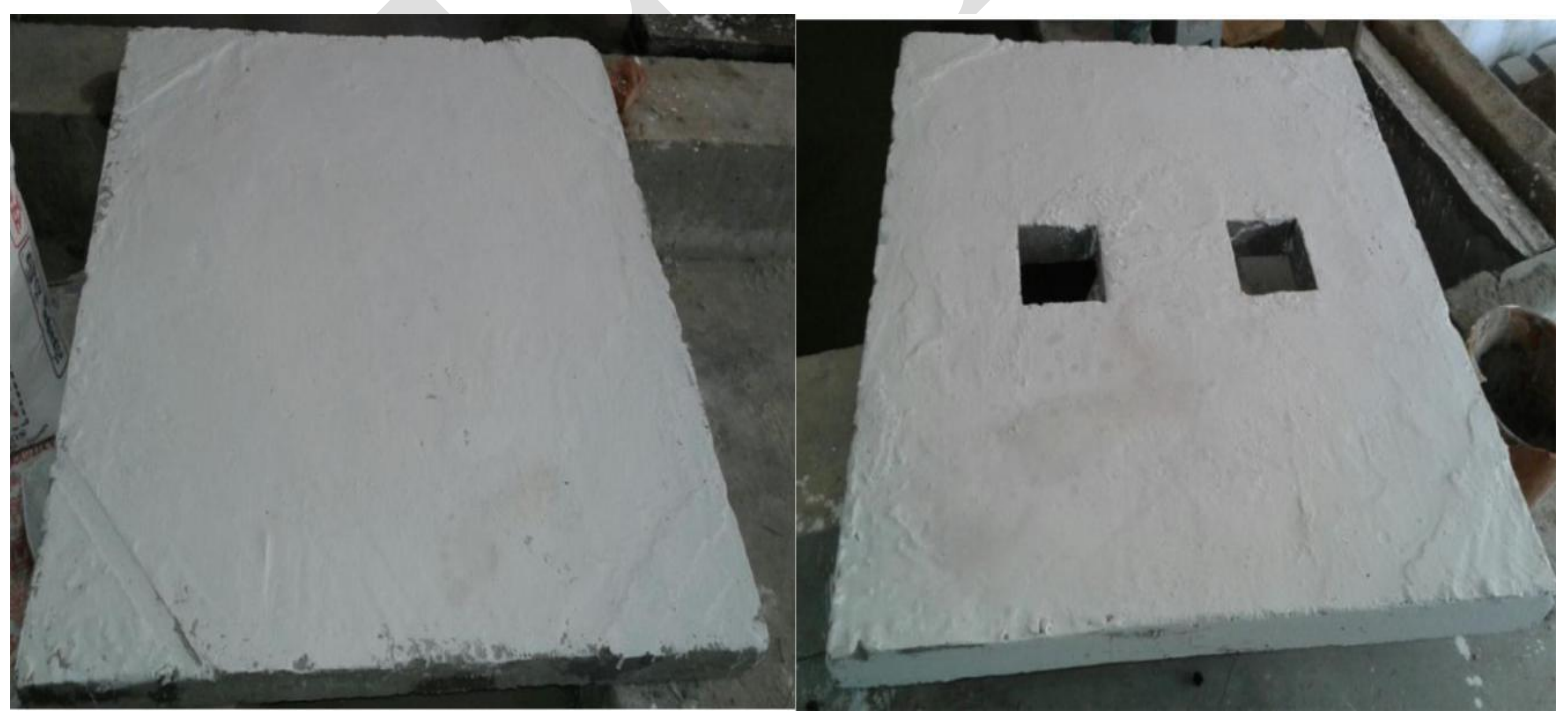

Figure: 1 Control slabs with and without opening 

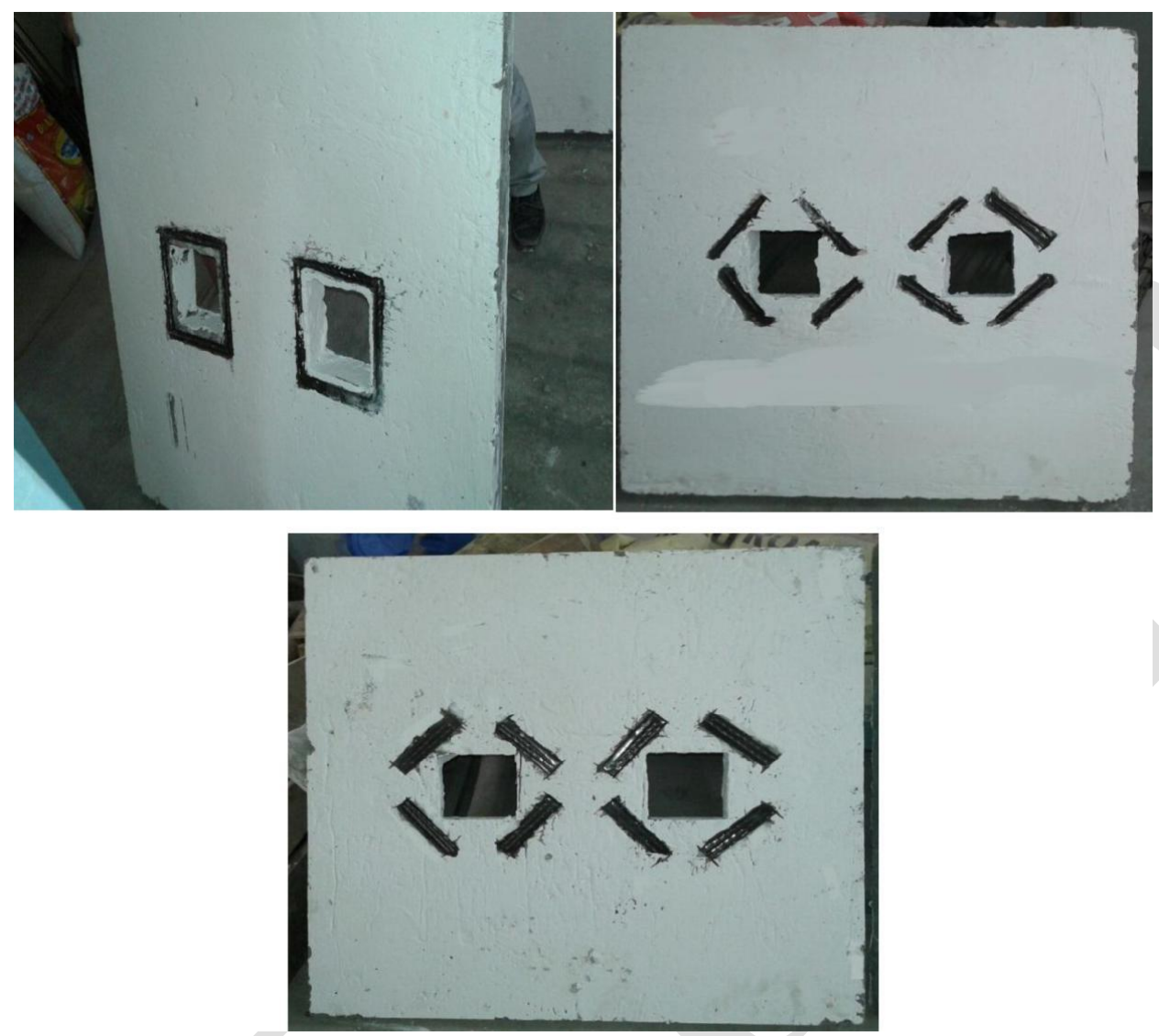

Figure: 2 Strengthened slab specimens

\subsection{EXPERIMENTAL SETUP AND TEST PROCEDURE}

In this experiment, each slab specimen was tested under simply-supported conditions. The load was applied locally on the surface of $10 \mathrm{~cm} \times 10 \mathrm{~cm}$ in the center of the specimen with a $500 \mathrm{kN}$ hydraulic jack. The tests were carried out in $50 \mathrm{~T}$ Loading Frame Machine with necessary fixtures as per ASTM C D 293.

Also the mid span displacement of each specimen was measured using linear variable differential transformer (LVDT) are shown in Figure. The specimen was supported on two edges subjected to single point loading. A load cell with 50T capacity was mounted on the plate fixed at the centre portion.

First, control slab without opening and un-strengthened slab with opening was tested to failure to investigate the load-carrying capacity and then, the strengthened slabs with GFRP rod by the above shown methods were tested. The load deflection behaviour was obtained automatically from the system attached are shown in figure 3. 


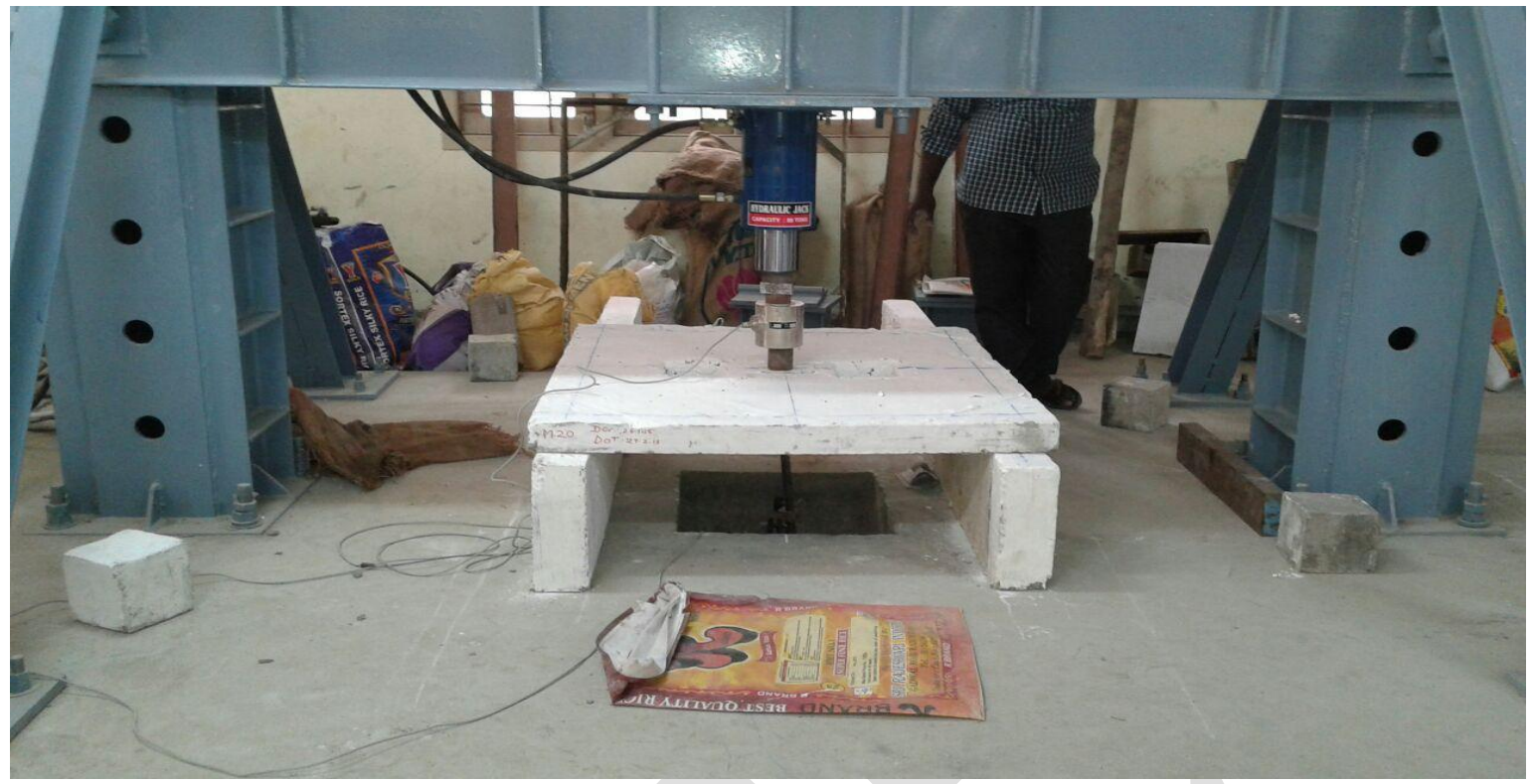

Figure: 3 Loading Arrangement on Slab Specimen

\section{RESULTS AND DISCUSSION}

The load deflection curves are shown in figure 4.

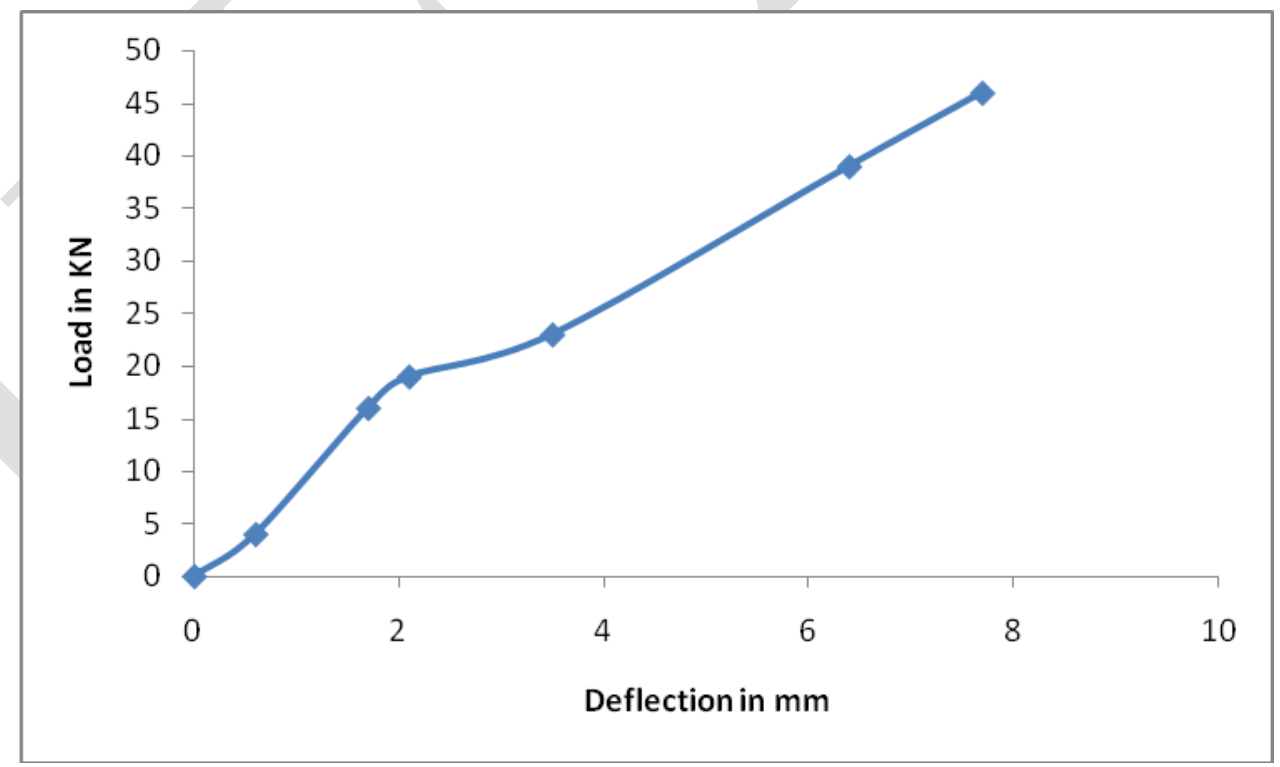

Figure: 4 load-deflection behaviour of CS1 
The control slab without opening (CS1) has been tested in order to obtain the load carrying capacity of the RC slab. For which the load-deflection behaviour has been studied. Thus the ultimate load is obtained as $46 \mathrm{kN}$ and the corresponding deflection is about $7.7 \mathrm{~mm}$.

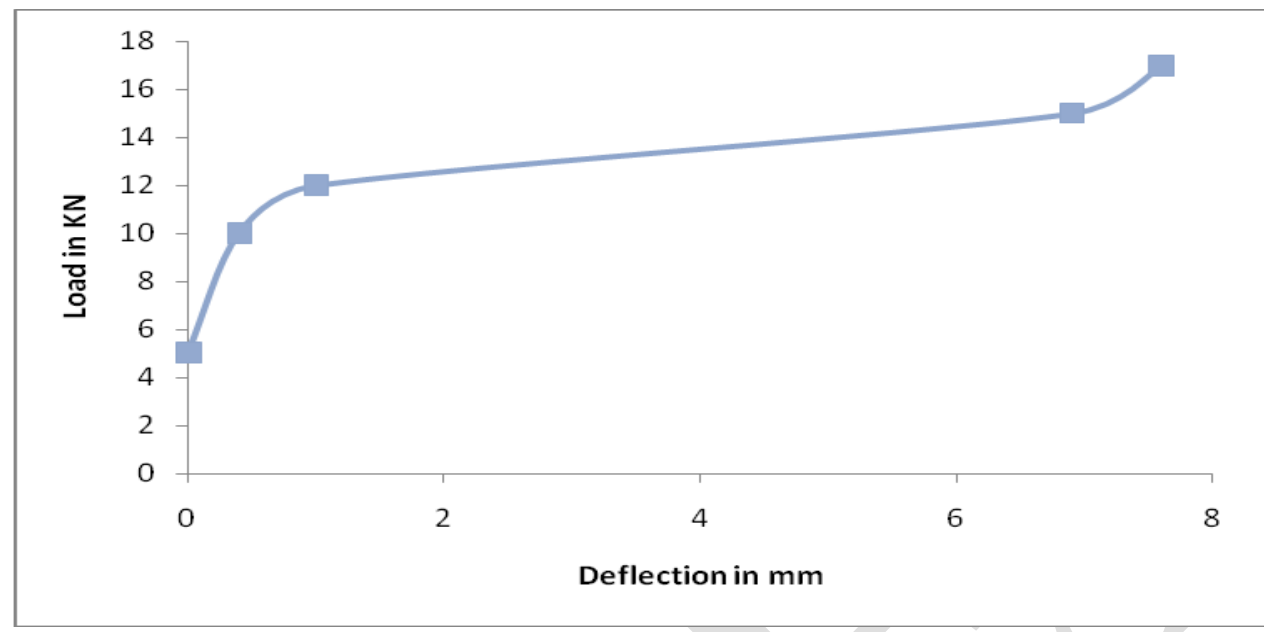

Figure: 5 Load-deflection behaviour of CS2

The control slab with opening and without strengthening (CS2) has been tested in order to obtain the load carrying capacity of the RC slab. For which the load-deflection behaviour has been studied. Thus the ultimate load is obtained as $17 \mathrm{kN}$ and the corresponding deflection is about $7.6 \mathrm{~mm}$ and shown in figure 5 .

Here the load carrying capacity is reduced when compare to the RC slab without opening, the reduction in the area by providing opening will have a greater influence in the load carrying capacity.

Thus it clearly shows the effect of opening on the structural member and need for strengthening a structure.

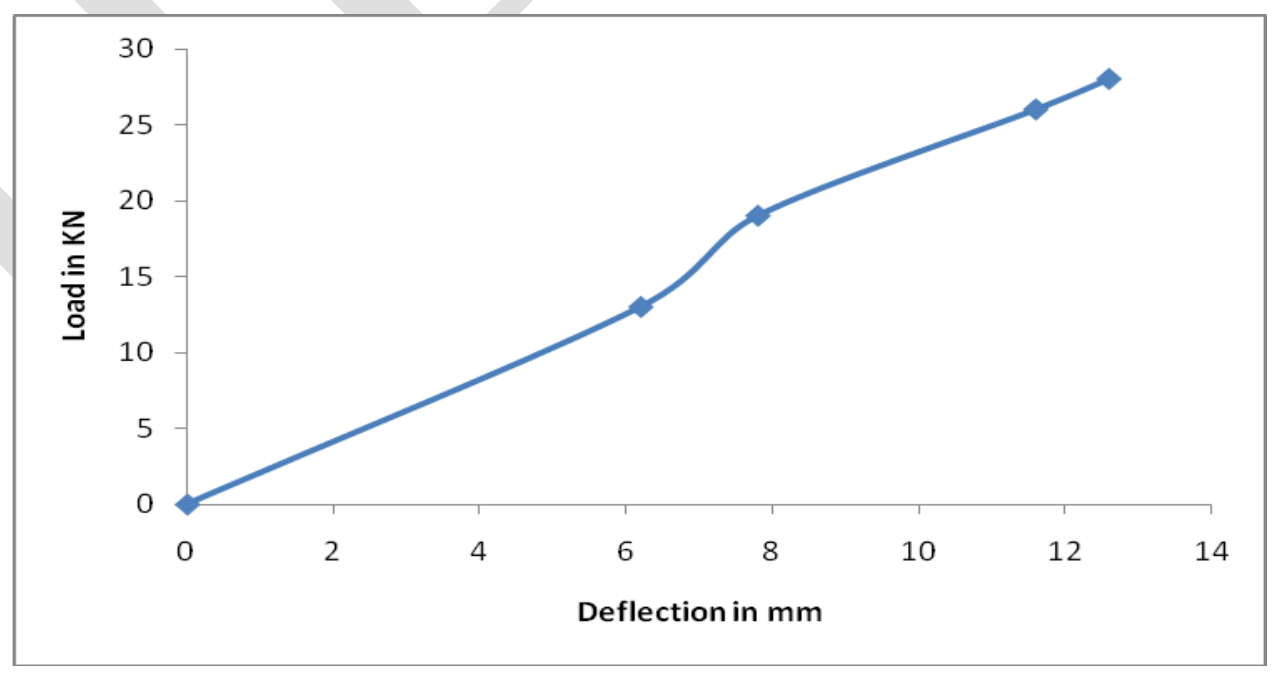

Figure: 6 Load-deflection behaviour of SS1 
The strengthened slab by placing GFRP rebar around the opening (SS1)has been tested in order to obtain the load carrying capacity of the RC slab. For which the load-deflection behaviour has been studied.

Thus the ultimate load is obtained as $28 \mathrm{kN}$ and the corresponding deflection is about $12.6 \mathrm{~mm}$ and shown in figure 6 .

Here, the reduction in the load carrying capacity due to the opening has been rectified and it has been improved to certain extend.

It shows that by strengthening the load carrying capacity can be increased as well as the problems due to providing opening can also minimized.

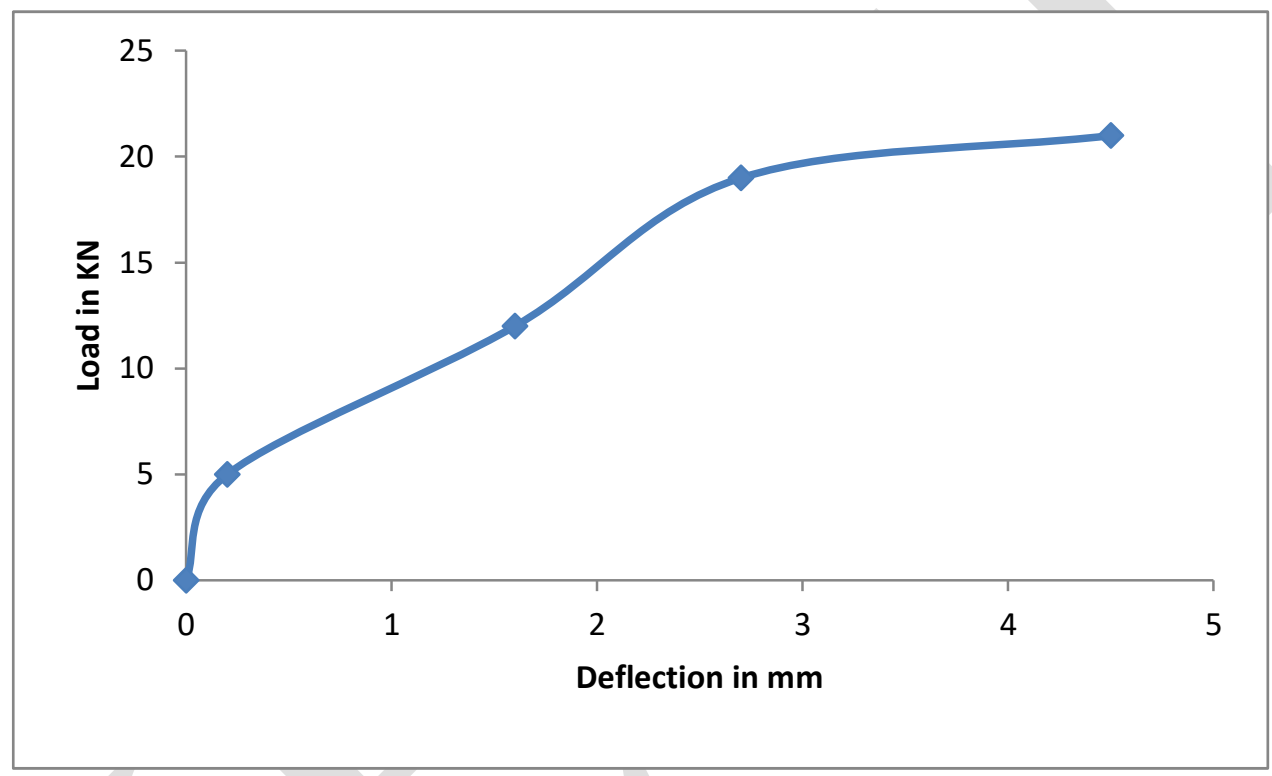

Figure: 7 Load-deflection behaviour of SS2

The strengthened slab by placing one GFRP rebar in diagonal pattern (SS2) has been tested in order to obtain the load carrying capacity of the RC slab. For which the load-deflection behaviour has been studied.

Thus the ultimate load is obtained as $21 \mathrm{kN}$ and the corresponding deflection is $4.5 \mathrm{~mm}$ and is shown in figure 7.

Here also the load carrying capacity has been improved but when compare to strengthening around the opening it is quite smaller improvement and the deflection has been reduced by this type of strengthening.

The strengthened slab by placing two GFRP rebar in diagonal pattern (SS3) around the opening has been tested in order to obtain the load carrying capacity of the RC slab. For which the loaddeflection behaviour has been studied. 
Thus the ultimate load is obtained as $22 \mathrm{kN}$ and the corresponding deflection is about $4.9 \mathrm{~mm}$. When compare to the above methods the load carrying capacity is slightly improved and the deflection has been greatly reduced and are shown in figure 8 .

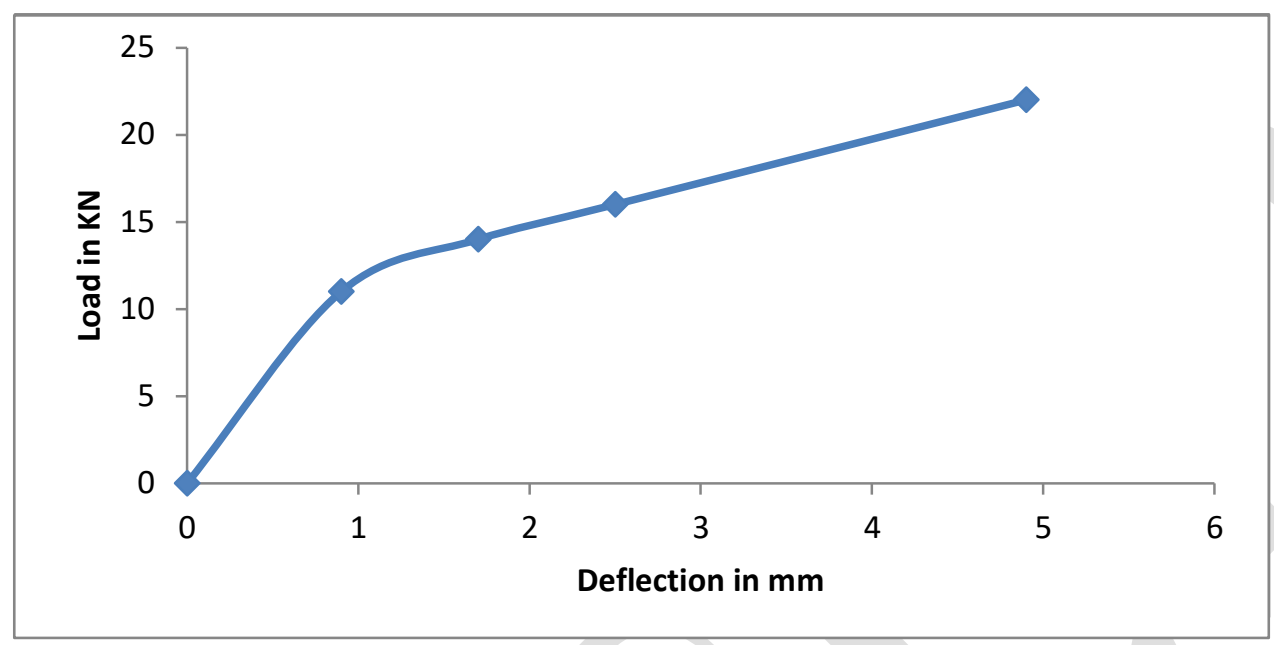

Figure: 8 Load-deflection behaviour of SS3

Various method of strengthening has been adopted in this study and their individual load deflection behaviour has been studied and the results were compared to know the effective method of strengthening and the effect of opening on the RC slab and discussed as follows.

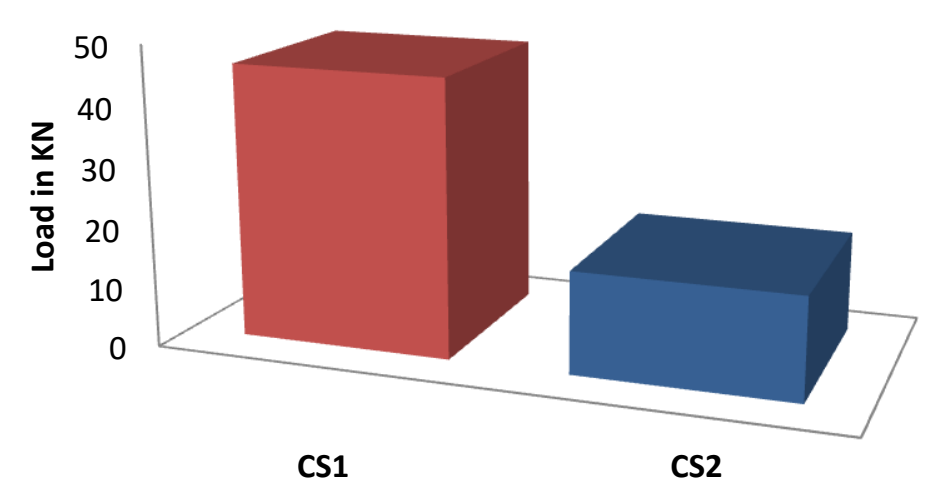

Specimen

Figure: 9 Comparisons of CS1 and CS2 
From the graph, the Load carrying capacity of control slab without opening (CS1) has been reduced when compare to the control slab with opening (CS2). It shows that the reduction of area by providing opening in $\mathrm{RC}$ slab will leads to the reduction in the load carrying capacity of the RC slab and are shown in figure 9 .

This is mainly due to the reduction in the stiffness of the structure.

Here the reduction of area of about 5\% then the load carrying capacity is decremented to $37 \%$.

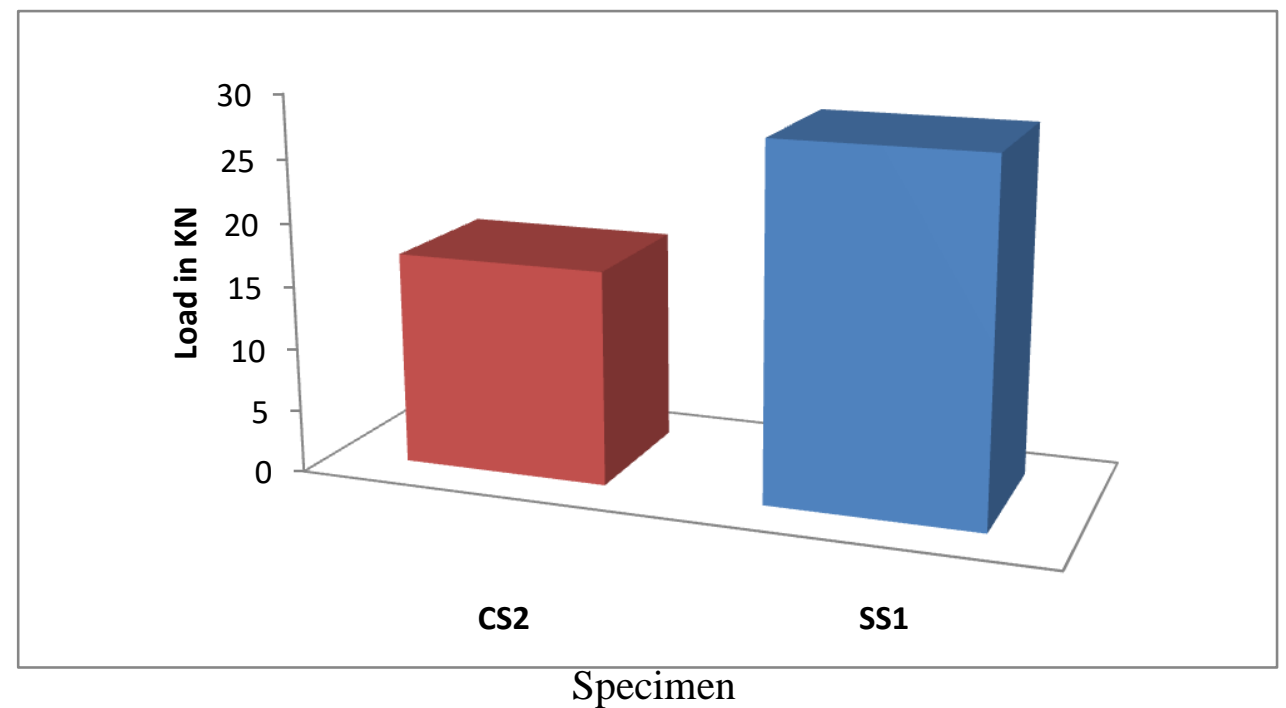

Figure: 10 Comparisons of CS2 and SS1

From the figure 10, the reduction in the Load carrying capacity of control slab with opening (CS2) has been improved by strengthening of RC slab around the opening (SS1).

It shows that while strengthening RC slab with openings by placing GFRP rod into the groove around the opening on flexure zone of RC slab will increase the load carrying capacity to a greater extend.

The load carrying capacity is improved about $39 \%$ by strengthening around the opening. Thus, the effect due to the provision of opening can be eliminated.

\section{CONCLUSION}

The following observations and conclusions can be made on the basis of the current experimental results

1. The degradation in the load carrying capacity due to the provision of openings has been observed and there was an increment in the load carrying capacity by strengthening using GFRP rods 
2. The NSM method of strengthening is the most promising technique which enhances the durability of the RC structure to a greater extent.

3. It was observed that reduction of area of about $5 \%$ by providing opening will reduce the load carrying capacity by $37 \%$

4. On strengthening around the opening, the load carrying capacity has been improved by $39 \%$ and the deflection has been reduced.

5. Meanwhile strengthening in diagonal form there was a slight improvement in the load carrying capacity to $23 \%$ and the deflection has been greatly reduced.

From the results it was shown that strengthening of the RC slab around the opening is the most effective method and economical too.

\section{REFERENCES}

[1] Yeoi Choi, Ik Hyun Park, Sang Goo Kang and Chang-Guen Cho, "strengthening of RC slab with symmetric opening using GFRP composite beams” Polymers 2013, Vol.5, pp.1352-1361, 2013.

[2] Seliem,H.M, Sumner.E.A. and Seracino. R, "Field testing on RC slabs with openings strengthened with CFRP", Proceedings of fourth International conference on FRP composites in civil engineering (CICE 2008), Zurich, Switzerland, pp. 22-24, July 2008.

[3] Smith.S and Kim.S.J. "Strengthening of one-way spanning RCslabs with cutouts using FRP composites", Construction and Building Materials Vol.23, Issue.4, pp. 1578-1590, 2009.

[4] Enochsson.O, Lundqvist. J, Taljsten. B, Rusinowski. P and Olofsson. T. "CFRP strengthened opening in Two-way concrete slabs-An experimental and numerical study", Construction and Building Materials, Vol. 21, Issue.4, pp. 810-826, 2007.

[5] L.Michel, E. Ferrier, D. Bigaud and A.Agbossou, "Criteria for punching shear failure mode in RC slabs reinforced by externally bonded CFRP”, Composite structures Vol. 81, pp. 438-449, 2007.

[6] Agbossou. A, Michel. L, Lagache. M and Hamelin. P, "Strengthening Slabs Using ExternallyBonded Strip Composites: Analysis of Concrete Covers on the Strengthening. Composites: Part B: Engineering, Vol. 39, pp. 1125-1135, 2008.

[7] Gilles Foreta and OualidLimam, "Experimental and numerical analysis of RC two-way slabs strengthened with NSM CFRP rods", Construction and Building Materials, Volume 22, Issue 10, October 2008. 